\title{
\begin{tabular}{l|l} 
Mibraries & DSpace@MIT
\end{tabular}
}

\author{
MIT Open Access Articles
}

\section{Mechanistically Guided Design of Ligands That Significantly Improve the Efficiency of CuH-Catalyzed Hydroamination Reactions}

The MIT Faculty has made this article openly available. Please share how this access benefits you. Your story matters.

Citation: Thomas, Andy, et al. "Mechanistically Guided Design of Ligands That Significantly Improve the Efficiency of CuH-Catalyzed Hydroamination Reactions." Journal of the American Chemical Society 140, 42 (Sept. 2018): p. 13976-84 doi 10.1021/JACS.8B09565 (C2018 Author(s)

As Published: 10.1021/JACS.8B09565

Publisher: American Chemical Society (ACS)

Persistent URL: https://hdl.handle.net/1721.1/126097

Version: Author's final manuscript: final author's manuscript post peer review, without publisher's formatting or copy editing

Terms of Use: Article is made available in accordance with the publisher's policy and may be subject to US copyright law. Please refer to the publisher's site for terms of use. 
Published in final edited form as:

J Am Chem Soc. 2018 October 24; 140(42): 13976-13984. doi:10.1021/jacs.8b09565.

\title{
Mechanistically Guided Design of Ligands that Significantly Improve the Efficiency of CuH-Catalyzed Hydroamination Reactions
}

\author{
Andy A. Thomas ${ }^{\# 1}$, Klaus Speck ${ }^{\# 1}$, Ilia Kevlishvili\#2, Zhaohong Lu ${ }^{1}$, Peng Liu², and Stephen \\ L. Buchwald ${ }^{1}$ \\ ${ }^{1}$ Department of Chemistry, Massachusetts Institute of Technology, Cambridge, Massachusetts \\ 02139, United States. \\ ${ }^{2}$ Department of Chemistry, University of Pittsburgh, Pittsburgh, Pennsylvania 15260, United \\ States. \\ \# These authors contributed equally to this work.
}

\begin{abstract}
Using a mechanistically guided ligand design approach, a new ligand (SEGFAST) for the CuHcatalyzed hydroamination reaction of unactivated terminal olefins has been developed, providing a 62-fold rate increase over reactions compared to DTBM-SEGPHOS, the previous optimal ligand. Combining the respective strengths of computational chemistry and experimental kinetic measurements, we were able to quickly identify potential modifications that lead to more effective ligands, thus avoiding synthesizing and testing a large library of ligands. By optimizing the combination of attractive, non-covalent ligand-substrate interactions and the stability of the catalyst under the reaction conditions, we were able to identify a finely-tuned hybrid ligand that greatly enables accelerated hydrocupration rates with unactivated alkenes. Moreover, a modular and robust synthetic sequence was devised, which allowed for practical, gram-scale synthesis of these novel hybrid ligand structures.
\end{abstract}

\section{Graphical Abstract}

\footnotetext{
Address Correspondence to: Professor Stephen L. Buchwald, 18-490 Dreyfus Laboratory, Department of Chemistry, Massachusetts Institute of Technology, 77 Massachusetts Avenue, Cambridge, MA 02139, tel: (617) 253-1885, FAX: (617) 253-3297, slbuchwald@mit.edu. SUPPORTING INFORMATION

The Supporting Information is available free of charge on the ACS Publications website at DOI: XX. Full computational and experimental procedures along with characterization data and copies of $1 \mathrm{H}, 13 \mathrm{C}, 31 \mathrm{P}$, and 19F, spectra, along with full kinetic data are provided.
} 


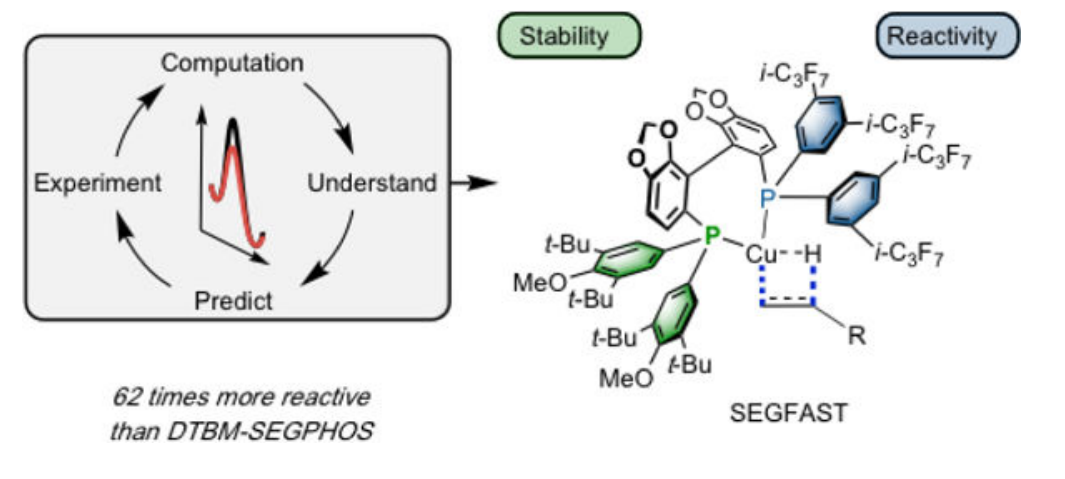

\section{INTRODUCTION}

In 2013, Buchwald, ${ }^{1}$ and Miura and Hirano ${ }^{2}$ independently demonstrated that copper hydride complexes $(\mathrm{LCuH})$ can catalyze the chemo- and enantioselective hydroamination reactions between olefins and hydroxylamine esters (Figure 1a). Since then the generality and applicability of this approach has been well demonstrated for a variety of substrates such as styrenes, ${ }^{3}$ vinylsilanes, ${ }^{4}$ alkynes ${ }^{5}$ and occasionally unactivated olefins, ${ }^{6}$ highlighting its enormous potential. Despite these achievements hydroamination reactions catalyzed by LCuH are not without limitations. ${ }^{7}$ For example, transformation of coupling partners such as cyclic, internal, and some unactivated terminal olefins often require elevated temperatures and increased reaction times compared to those of activated substrates. ${ }^{8}$ In particular, an efficient anti-Markovnikov hydroamination reaction with unactivated terminal olefins is highly desirable, because the products of these reactions are frequently found in bioactive molecules. ${ }^{9}$ These compounds are traditionally prepared by transforming carbonyl compounds, amides or alkyl electrophiles into their corresponding amine products. ${ }^{10}$ From a strategic standpoint, hydroamination reactions between olefins and electrophilic amine sources provide one of the most straightforward and general avenues to access these important motifs, especially since the precursors are typically stable, readily available, and easy to handle. ${ }^{11}$

Recently, several experimental ${ }^{12,13}$ and computational ${ }^{14}$ mechanistic investigations have appeared on both $\mathrm{CuH}$ catalyzed hydroamination and hydroboration reactions, revealing the same basic catalytic cycle, comprised of four elementary steps: hydrocupration (I), oxidative addition (II), reductive elimination (III) and $\sigma$-bond metathesis (IV) (Figure 1b). ${ }^{15}$ These studies demonstrated that the rate determining step (RDS) can vary between different olefinic substrates. Specifically, the RDS for activated substrates, such as styrenes, is often the catalyst regeneration by $\sigma$-bond metathesis, whereas it changes to the hydrocupration step for unactivated internal or terminal alkenes, ${ }^{12}$, 14a indicating that the lower reactivity observed for unactivated olefins is the direct result of higher barriers for hydrocupration.

Typically, reaction development in this area has relied on empirical observations pertaining to which catalytic system provides the fastest reaction rates. ${ }^{11}$ For example, reactions with SEGPHOS L1 supported LCuH catalysts are often found to be slower; whereas, the use of sterically more demanding DTBM-SEGPHOS L2 derivative is often key to achieving higher reactivity, especially in the reactions of unactivated olefins (Figure 1c). ${ }^{14 a}$ 
Beginning last year, our laboratories sought to unravel the theoretical foundations that lead to favorable hydrocupration events between $\mathrm{LCuH}(\mathrm{L}=\mathbf{L} \mathbf{1}$ and $\mathbf{L 2})$ and various unactivated olefins, by performing the ligand-substrate interaction model analysis on this crucial step (Figure 2a). ${ }^{14 a}$ Using this approach, the contributions of the different types of catalystsubstrate interactions to the overall activation energy $\left(\Delta E^{\dagger}\right)$ were split into three categories: (1) the distortion energy required for the $\mathrm{LCuH}$ and the substrate to reach their transition state geometries $\left(\Delta E_{\text {dist }}\right) ;(2)$ the through-space interactions between the ligand and the substrate ( $\left.\Delta E_{\text {int-space }}\right)$; and (3) the through-bond interactions between the $\mathrm{CuH}$ moiety and the substrate $\left(\Delta E_{\text {int-bond }}\right)$. In the hydroamination reactions when SEGPHOS L1 and DTBMSEGPHOS L2 ligands were employed, the $\Delta E_{\text {dist }}$ and $\Delta E_{\text {int-bond }}$ terms were not found to correlate with the overall activation energies $\left(\Delta E^{\$}\right)$; however, excellent linear correlations were observed with $\Delta E_{\text {int-space. }}$ This suggested that the $t$-butyl substituents at the 3- and 5positions on the $P$-aryl ${ }_{2}$ groups in DTBM-SEGPHOS L2 promote stabilizing non-covalent interactions (Figure $2 \mathrm{~b}$ ). Indeed, dissecting the $\Delta E_{\text {int-space }}$ term into its individual components revealed that attractive London dispersion forces $\left(\Delta E_{\mathrm{disp}}\right)$ between the 3,5-di- $t$ butyl substituents on the $P$-aryl ${ }_{2}$ groups and the substrate were the main contributing factor to achieve high catalyst activity with the DTBM-SEGPHOS L2 ligand. While the London dispersion interactions are relatively weak $(0.5 \sim 1.5 \mathrm{kcal} / \mathrm{mol}$ for interactions with each $t$-Bu substituent), ${ }^{14 a}, 16$ collectively they significantly reduce activation barriers via transition state stabilization. ${ }^{17,18}$ Moreover, these conclusions were experimentally validated through ligand synthesis and subsequent kinetic analysis. ${ }^{14 \mathrm{a}}$

Building upon this knowledge, we undertook the challenge of designing a new family of ligands based on SEGPHOS L1 to more efficiently facilitate the copper-hydride catalyzed anti-Markovnikov hydroamination reaction with terminal olefins. We theorized a more effective ligand system can be rationally designed by retaining the stabilizing dispersion effects of DTBM-SEGPHOS L2 while incorporating other types of stabilizing through-bond and/or through-space interactions. ${ }^{19}$ Specifically, we surmised that other types of weak noncovalent interactions with the olefin substrate,${ }^{20}$ may be harnessed by installation of heteroatom-containing substituents on the $P$-aryl 2 groups. In addition, the through-bond stabilization between the $\mathrm{CuH}$ moiety and the substrate in the hydrocupration transition state can be fine-tuned by altering the electronic character of the ligands. However, when designing catalysts capable of promoting reactivity through an assortment of stabilizing interactions, infinite possibilities are conceivable. With the unique ability to computationally quantify and experimentally verify these interactions, an iterative catalyst design approach was envisioned (Figure 3). ${ }^{21,22}$ This approach comprised of four stages: (1) experimentally identify a suitable class of ligand derivatives; (2) using computational analysis to understand what key interactions can stabilize the transition state; (3) using this knowledge to computationally predict a more effective ligand and (4) experimentally test the ligand providing feedback for the next round of ligand optimization.

\subsection{Kinetic and computational analysis of SEGPHOS Ligands.}

\subsubsection{Preliminary Experimental Investigations with Symmetric SEGPHOS}

Ligands.-As described above, previous investigations indicated that primarily bulky substituents at the 3 and 5-positions on the $P$-aryl 2 groups were critical in facilitating the 
hydrocupration event with terminal olefins. ${ }^{14 a}$ This finding directed our preliminary studies to investigate SEGPHOS derivatives with substituents possessing different steric (TMS) and electronic $\left(\mathrm{CF}_{3}\right)$ properties at these positions (Scheme 1). ${ }^{23}$ To kinetically quantify and compare the effects of these ligands on the hydrocupration event 4-phenyl-1-butene (1) and $O$-benzoyl- $N, N$-dibenzylhydroxylamine (2) were selected as model substrates, because a first order dependence on the olefin had been shown previously for the hydroamination reaction with DTBM-SEGPHOS L2. ${ }^{24}$ The initial rates were measured for the reaction with each ligand by monitoring the formation of hydroamination product $\mathbf{3}$ under typical copper hydride hydroamination conditions $\left(1.0 \mathrm{~mol} \% \mathrm{Cu}(\mathrm{OAc})_{2}, 1.1 \mathrm{~mol} \%\right.$ ligand, $0.36 \mathrm{M}$ in THF, $23^{\circ} \mathrm{C}$ ) utilizing dimethyoxymethylsilane (DMMS, 3.0 equiv/1) as the stoichiometric reductant. To allow for a straightforward comparison, the rate of hydroamination was measured first with DTBM-SEGPHOS L2 $(8.60 \pm 0.05) \times 10^{-6} \mathrm{M} / \mathrm{s}$ so that the rates could be normalized (Scheme 1).

Following our standard protocol, the reaction employing TMS-SEGPHOS L3 was found to be 3.3 times faster than that with DTBM-SEGPHOS L2, suggesting that the larger TMS substituents, with a Taft value of $E_{S}{ }^{\prime}=1.79$, have stronger interactions with the olefin substrate than the $t$-Bu groups $\left(E_{S}{ }^{\prime}=1.49\right)$ in DTBM-SEGPHOS L2 (Scheme 1). ${ }^{25}$ Interestingly, the hydroamination with the $\mathrm{CF}_{3}$-SEGPHOS $\mathbf{L} 4$ derivative underwent the hydrocupration event 6.7 times faster than $\mathbf{L 2}$ and 2.0 times faster than $\mathbf{L 3}$ even though the $\mathrm{CF}_{3}$ groups $\left(E_{S}{ }^{\prime}=0.78\right)$ are smaller and presumably less polarizable. ${ }^{26}$ This suggested that the fluorine-containing substituents have additional stabilizing effects that are stronger than simple London dispersion interactions as observed with $\mathbf{L} \mathbf{2}$ and $\mathbf{L 3}$. The origin for this significant and unexpected rate increase for $\mathbf{L} \mathbf{4}$ was revealed by computational investigations as detailed below.

\subsubsection{Computational Analysis of the Origin of Reactivity with Symmetric SEGPHOS Derivatives.-The preliminary experimental studies revealed promising} results with the $\mathrm{CF}_{3}$-SEGPHOS L4 derivative. However, it was unclear what further modifications could lead to additional reactivity enhancement. ${ }^{19,27}$ Although successful predictions of new transition metal catalysts from computational results alone are still rare, ${ }^{28}$ several examples have recently been described wherein a combination of computational and experimental evaluations has led to the discovery of catalysts with improved reactivity and selectivity. ${ }^{19,21}$ Such synergetic efforts effectively utilize the predictive power of computation, while the experimental verification helps resolve the uncertainty of calculated energies and issues that cannot be readily addressed by computations alone, such as catalyst decomposition. ${ }^{29}$

3.1.2.1 Computational Methods: Geometry optimizations and single-point energy calculations were carried out using Gaussian 09. ${ }^{30}$ Geometries of intermediates and transition states were optimized using the B3LYP functional ${ }^{31}$ with a mixed basis set of $\mathrm{SDD}$ for $\mathrm{Cu}$ and $6-31 \mathrm{G}(\mathrm{d})$ for other atoms in the gas phase. Vibrational frequency calculations were performed for all of the stationary points to confirm if each optimized structure is a local minimum or a transition state structure. Truhlar's quasi-harmonic corrections $^{32}$ were applied for entropy calculations using $100 \mathrm{~cm}^{-1}$ as the frequency cut-off. 
Solvation energy corrections were calculated in THF solvent with the CPCM continuum solvation model ${ }^{33}$ based on the gas-phase optimized geometries. The $\omega$ B97X-D functional ${ }^{34}$ with a mixed basis set of SDD for $\mathrm{Cu}$ and $6-311+\mathrm{G}(\mathrm{d}, \mathrm{p})$ for other atoms was used for solvation single-point energy calculations. The computed gas-phase activation energy $\left(\Delta E^{\dagger}\right)$ was dissected using the following ligand-substrate interaction model analysis. ${ }^{35}$

$$
\Delta E^{\ddagger}=\Delta E_{\text {dist }}+\Delta E_{\text {int-bond }}+\Delta E_{\text {int-space }} \quad \text { eq. } 1
$$

The distortion energy $\left(\Delta E_{\mathrm{dist}}\right)^{35}$ is the sum of the energies required to distort the $\mathrm{LCuH}$ catalyst and the substrate into their transition state geometries. $\Delta E_{\text {int-space }}$ was calculated from the interaction energy of a supramolecular complex of the phosphine ligand and the olefin substrate at the transition state geometry but in the absence of the $\mathrm{CuH}$ moiety $\left(\Delta E_{\text {int-space }}=E_{\text {lig+sub }}-E_{\text {lig }}-E_{\text {sub }}\right)$. Then, the through bond interaction was calculated from $\Delta E_{\text {int-bond }}=\Delta E^{+}-\Delta E_{\text {dist }}-\Delta E_{\text {int-space }}$. The $\Delta E_{\text {dist }}$ and $\Delta E_{\text {int-space }}$ were both calculated using the $\omega$ B97X-D functional with the SDD basis set for $\mathrm{Cu}$ and $6-311+\mathrm{G}(\mathrm{d}, \mathrm{p})$ for other atoms. The $\omega \mathrm{B} 97 \mathrm{X}-\mathrm{D}$ functional was chosen because it has been shown to accurately describe noncovalent interactions, ${ }^{36}$ which we expected to be important in this system. The computed free energy barriers using this method provided very good agreement with the experimental reaction rate constants (see SI for details and comparison with results from other functionals and solvation models). The through-space interaction energy ( $\left.\Delta E_{\text {int-space }}\right)$ between the ligand and the substrate is further dissected according to the following equation:

$$
\Delta E_{\text {int-space }}=\Delta E_{\text {Pauli }}+\Delta E_{\text {elstat }}+\Delta E_{\text {pol }}+\Delta E_{\text {ct }}+\Delta E_{\text {disp }} \quad \text { eq. } 2
$$

In accordance with our previous study, the dispersion energy component $\left(\Delta E_{\text {disp }}\right)$ was obtained from the difference of interaction energies calculated using MP2 and HF. The MP2 calculations were performed with Q-Chem 5.0 using the SOS(MI)-MP2 method in combination with the dual-basis set approach utilizing the db-cc-pVTZ basis set. ${ }^{37}$ The $\Delta E_{\text {Pauli }}, \Delta E_{\text {elstat }}, \Delta E_{\text {disp }}, \Delta E_{\text {pol }}$, and $\Delta E_{\mathrm{ct}}$ terms in eq 2 were calculated using the secondgeneration energy decomposition analysis based on absolutely localized molecular orbitals ${ }^{38}$ (ALMO-EDA) method implemented in Q-Chem 5.0. ${ }^{39}$ The second generation ALMO-EDA provides further decomposition of the Pauli and electrostatic interaction $\left(\Delta E_{\text {rep }}\right)$ term into Pauli repulsion $\left(\Delta E_{\text {Pauli }}\right)$ and electrostatic $\left(\Delta E_{\text {elstat }}\right)$ energies, which is important in the analysis of through-space electrostatic interactions with the fluorinated ligands. To avoid double counting of dispersion, HF method with the 6-311G(d,p) basis set was employed in the energy decomposition analysis (EDA) calculations.

3.1.2.2. Computational Analysis of Symmetric-SEGPHOS Ligands.: In order to fully understand the underlying principles and interactions that lead to the enhanced rate, an indepth computational analysis was performed to study the origin of the different

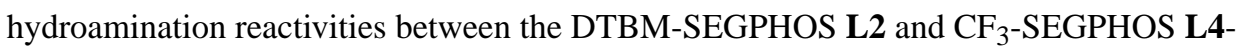
supported $\mathrm{CuH}$ catalysts. 
The activation energies of the rate-determining hydrocupration transition states were computed using propene (4) as the model substrate with the method outlined above (Table 1). The computed barrier of hydrocupration with the $\mathrm{CF}_{3}$-SEGPHOS $\mathbf{L} 4 \mathrm{CuH}$ complex was in good agreement with the experimentally observed rate increase with $\mathbf{L} \mathbf{4}$ compared to DTBM-SEGPHOS L2CuH $\left(\Delta \Delta G_{\text {comp }}^{\dagger}=1.5 \mathrm{kcal} / \mathrm{mol} v s \Delta \Delta G_{\text {exp }}^{\dagger}=1.1 \mathrm{kcal} / \mathrm{mol}\right)$. In order to quantify the different factors that lead to the improved reactivity, the ligand-substrate interaction model analysis was employed to dissect the overall hydrocupration activation energies (Eqs. 1 and 2, see Computational Methods for details). Energy-decomposition analysis of the hydrocupration transition state with $\mathbf{L} 4 \mathrm{CuH}$ revealed that the increase in the reaction rate was due to significantly stronger through-bond interactions $\left(\Delta E_{\text {int-bond }}\right)$ resulting in an extra $2.3 \mathrm{kcal} / \mathrm{mol}$ stabilization of TS-4 compared to the DTBM-SEGPHOSbound TS-2. This is because of the electron-withdrawing nature of the $\mathrm{CF}_{3}$-substitutents which consequently results in enhanced Lewis acidity of the $\mathrm{CuH}$ catalyst and more favorable binding of the olefin substrate (see SI for details). While the through-space interaction energies ( $\left.\Delta E_{\text {int-space }}\right)$ are comparable in TS-2 and TS-4, the origins are different. Using the second-generation ALMO-EDA methods, the $\Delta E_{\text {int-space }}$ term was further dissected into its individual energy components (Eq. 2). While TS-2 is stabilized by stronger attractive London dispersion $\left(\Delta E_{\text {disp }}=-13.3 \mathrm{kcal} / \mathrm{mol}\right.$ for TS-2 compared to $-10.7 \mathrm{kcal} / \mathrm{mol}$ for TS-4), electrostatic interactions are more favorable in TS-4 $\left(\Delta E_{\text {elstat }}=0.3 \mathrm{kcal} / \mathrm{mol}\right.$ for TS-2 compared to $-1.5 \mathrm{kcal} / \mathrm{mol}$ for TS-4). The optimized geometry of TS-4 revealed multiple $\mathrm{C}-\mathrm{F} \cdots \mathrm{H}-\mathrm{C}$ contacts, which are responsible for the through-space electrostatic interactions between $\mathbf{L} \mathbf{4}$ and the olefin substrate thereby lowering $\Delta E^{\ddagger}$ (Figure 4).

Although the use of $\mathrm{CF}_{3}$-SEGPHOS $\mathbf{L} 4$ leads to a relatively moderate increase of reactivity, the computational analysis suggested types of modifications that might result in a more effective ligand. Considering that the $\mathrm{CF}_{3}$-SEGPHOS L4 ligated $\mathrm{LCuH}$ complex has weakened dispersion interactions when compared to the $\mathbf{L} \mathbf{2} \mathbf{C u H}$ complex, we hypothesized that the installation of a larger perfluorinated substituent would be beneficial. Since the $i$ $\mathrm{C}_{3} \mathrm{~F}_{7}$ group is sterically more demanding than $\mathrm{CF}_{3}$, we assumed that it should increase stabilizing London dispersion, while maintaining the favorable through-space electrostatic attractions and through-bond electronic effects.

Indeed, the calculated hydrocupration transition state TS-5 indicated that the use of $i-\mathrm{C}_{3} \mathrm{~F}_{7}$ SEGPHOS L5 as the ligand led to an additional $1.5 \mathrm{kcal} / \mathrm{mol}$ lower activation energy compared to the hydrocupration with $\mathbf{L} 4 \mathbf{C u H}$ (Table 1).

The ligand-substrate interaction model analysis validated our hypothesis, as the $\Delta E_{\mathrm{dist}}$ and $\Delta E_{\text {int-bond }}$ terms of TS-5 remained largely unchanged when compared to TS-4. Meanwhile, the through-space interaction of TS-5 was $1.7 \mathrm{kcal} / \mathrm{mol}$ more stabilizing. Further dissection of the through-space interactions revealed that the primary reason for the increased reactivity was due to the increased London-dispersion interactions $\left(\Delta E_{\text {disp }}\right)$ in TS-5. To validate this computational prediction, we needed to experimentally measure the reactivity of $i-\mathrm{C}_{3} \mathrm{~F}_{7}$ SEGPHOS-supported CuH catalyst $\mathbf{L 5 C u H}$.

\subsubsection{Synthesis and Kinetic Analysis of Hydroamination with the Symmetric i- $\mathrm{C}_{3} \mathrm{~F}_{7}$-SEGPHOS Ligand.-Informed by the computational predictions described above,}


we set out to synthesize ligand $\mathbf{L 5}$. Adopting a closely related report by $\mathrm{Yu}$, we were able to prepare $\mathbf{L 5}$ from dibromide 5 and bis- $\left(3,5-i-\mathrm{C}_{3} \mathrm{~F}_{7}-\mathrm{C}_{6} \mathrm{H}_{3}\right)_{2} \mathrm{PBr}(\mathbf{6})$ in a single step (Scheme 2a). 40

When $\mathbf{L 5}$ was employed with the standard catalytic conditions, vide supra, the formation of hydroamination product $\mathbf{3}$ was observed to be 61 times faster than with $\mathbf{L 2}$, indicating that increased London dispersion interactions were indeed facilitating the hydrocupration event. However, only a short burst of reactivity was observed under the reaction conditions employing L5. This suggests that the $\mathbf{L 5 C u H}$ complex, although an active catalyst, was not stable under the reaction conditions (Figure 6, red curve). ${ }^{41}$ This catalyst decomposition is most likely the consequence of the diminished Lewis basicity of the phosphorus atoms in L5, due to the electron-withdrawing nature of the $i-\mathrm{C}_{3} \mathrm{~F}_{7}$ substituents which results in weaker binding to the copper center. In order to exhibit both high reactivity and stability, the Lewis acidity of the copper center needed to be finely tuned.

3.1.5. Hybrid-SEGPHOS Ligands-To harness the increased reactivity that we observed using the $i-\mathrm{C}_{3} \mathrm{~F}_{7}$ substituents without sacrificing the stability of the resulting complex, we had two options: either to synthesize and test various new derivatives with different substituents, in order to find a suitable ligand that provides a catalyst system that combines high activity and stability, or exchange one $P$-aryl 2 substituent for a more electrondonating group in order to stabilize the resulting copper complex. To avoid significant structural changes at the 3- and 5-positions of the aryl groups, we reasoned that the merger of DTBM-L2 and $i-\mathrm{C}_{3} \mathrm{~F}_{7}-\mathbf{L 5}$, the ligands with higher catalyst stability and reactivity, might result in the perfect balance of their respective beneficial interactions. This hypothesis found further support in examining the transition-state structure TS-5, in which the improved through-space ligand-substrate interactions primarily arise from the $\mathrm{C}-\mathrm{F} \cdots \mathrm{H}-\mathrm{C}$ interactions in the $1^{\text {st }}$ and $4^{\text {th }}$ quadrants (Figure 5). The $i-\mathrm{C}_{3} \mathrm{~F}_{7}$ groups in the $2^{\text {nd }}$ and $3^{\text {rd }}$ quadrants are further away from the substrate, and thus are less significant in promoting the hydrocupration step. Therefore, exchanging the $P$-aryl ${ }_{2}$ groups in the $2^{\text {nd }}$ and $3^{\text {rd }}$ quadrants was not expected to significantly impact the enhanced reactivity gained from the $i-\mathrm{C}_{3} \mathrm{~F}_{7}$ moieties.

\subsubsection{Computational Studies of Hydrocupration with Hybrid-SEGPHOS}

Ligands: The computational investigations showed that the hydrocupration barrier for the hybrid SEGPHOS derivative $\mathbf{~} \mathbf{6 C u H}$ was similar to that of the symmetric derivative $\mathbf{~} \mathbf{5} \mathbf{C u H}$ (see Table 1). In the lowest energy transition state structure with L6 (TS-6, Figure 5), the methyl group on propene (4) prefers to be placed in the $i$ - $\mathrm{C}_{3} \mathrm{~F}_{7}$-occupied $1^{\text {st }}$ quadrant, rather than the DTBM-occupied $3^{\text {rd }}$ quadrant (TS-6a, Figure 5), indicating the C-F-.H-C noncovalent interactions with the $i-\mathrm{C}_{3} \mathrm{~F}_{7}$ group are more favorable than the $\mathrm{C}-\mathrm{H} \cdots \mathrm{H}-\mathrm{C}$ interactions with the $t$-Bu group. Further energy decomposition analysis showed similar through-space interaction energies ( $\left.\Delta E_{\text {int-space}}\right)$ in TS-6 and TS-5 (Table 1). While electrostatic interactions in TS-6 were slightly decreased relative to those in TS-5, London dispersion interactions were increased as a result of the larger $t$-butyl substituents in the $2^{\text {nd }}$ and $3^{\text {rd }}$ quadrants of TS-6. This finding indicated, that a comparable energy barrier of hydrocupration might be obtained from $\mathbf{L} 6 \mathrm{CuH}$. 
3.1.5.2 Synthesis of Hybrid-SEGPHOS Ligands: To verify our hypothesis, a practical synthetic sequence had to be developed to prepare this hybrid ligand. After extensive experimental effort, a modular three-step sequence was established (Scheme $2 b$ ). The installation of the bis- $\left(3,5-\mathrm{CF}_{3}-\mathrm{C}_{6} \mathrm{H}_{3}\right)_{2} \mathrm{P}$ subunit was achieved by trapping monomagnesiated 5 with freshly prepared bis- $\left(3,5-i-\mathrm{C}_{3} \mathrm{~F}_{7}-\mathrm{C}_{6} \mathrm{H}_{3}\right)_{2} \mathrm{PBr}(\mathbf{6})$. After, the introduction of the DTBM-P $(\mathrm{O})$ moiety, via a palladium catalyzed cross-coupling reaction with DTBM phosphine oxide 7, and subsequent reduction, L6 was obtained in $26 \%$ yield over 3 steps. $^{42}$

3.1.5.3 Kinetic Analysis of Hybrid-SEGPHOS Ligands: Following our standard kinetic protocol, $\mathbf{L 6}$ was employed with our usual catalytic conditions and the formation of hydroamination product $\mathbf{3}$ was found to be 62 times faster than that when using $\mathbf{L 2}$, indicating that the rate enhancement observed with the symmetric $\mathbf{L} \mathbf{5 C u H}$ complex was maintained (Figure 6, black curve). We also noted that no detectable catalyst decomposition was observed with $\mathbf{L 6}$ under the reaction conditions, validating our hypothesis that the hybrid system could maintain stability without sacrificing reactivity. ${ }^{38}$

\subsubsection{Demonstration of Hybrid-SEGPHOS Ligand L6 under Preparative}

Conditions.-In order for this newly developed ligand to be useful in a synthetic context, the observed rate increase would need to be maintained at preparatively relevant scales and on substrates bearing functional groups. After slight optimization of the reaction conditions, the scope of olefins was established using hydroxylamine ester $\mathbf{2}$ as the amine source (Table 2). The hydroamination of terminal olefins that contained various functional groups were surveyed at room temperature. Epoxide 8, ester 9, silyl ether 10, and ketal 11 all provided the desired tertiary amine product in excellent yield. Moreover, substrates that contained a variety of heterocycles, such as piperazine 12, morpholine $\mathbf{1 3}$, and thiophene 14 also underwent smooth hydroamination at room temperature. Stronger Lewis bases found in heterocyclic compounds like indole 15 , benzothiazole $\mathbf{1 6}$, pyrimidine $\mathbf{1 7}$, and in quinolines 18 and 19 slightly inhibited the reaction, and thus their reactions required slightly elevated temperatures $\left(40^{\circ} \mathrm{C}\right)$ to reach full conversion within 3 hours. To compare our new catalyst to the current state-of-the-art catalyst, $\mathbf{L 2}$, epoxide $\mathbf{8}$ and ester $\mathbf{9}$ were subjected to these reaction conditions employing DTBM-L2 as the ligand. ${ }^{43}$ Diminished yields of 17 and $29 \%$ were observed compared to 89 and $94 \%$ with L6, respectively. This demonstrates that the rate enhancement using this catalyst system is maintained under preparative reaction conditions.

\section{CONCLUSION}

This study demonstrates how the combination of mechanistic insights, computational prediction, and experimental verification can successfully benefit ligand development. Using this synergistic approach we were able to discover a new hybrid ligand $\mathbf{L 6}$ that is capable of promoting the anti-Markovnikov hydroamination of unactivated, terminal olefins with a 62 fold rate increase compared to DTBM-SEGPHOS L2. By employing energy decomposition analysis methods, we were able to deconvolute each individual energy contributions of the steric, electronic, and dispersion effects that comprise the hydrocupration barrier. During the course of our investigation we identified that in addition to London dispersion, both 
electrostatic C-F..H-C non-covalent interactions and inductive effects of the $i-\mathrm{C}_{3} \mathrm{~F}_{7}$ substituents are capable of lowering the energy barrier for hydrocupration even further. Ultimately, the merger of both DTBM and $i-\mathrm{C}_{3} \mathrm{~F}_{7}$ substituents was key to success in designing $\mathbf{L 6}$ with balanced stability and reactivity. Furthermore, a modular and robust synthetic sequence to access these novel hybrid ligand structures was devised, that allowed for its gram-scale synthesis. In addition, the effectiveness of the catalyst system employing L6 was proven under preparative conditions. We anticipate that this rational ligand design approach can be utilized in other catalytic systems providing accelerated reaction development.

\section{Supplementary Material}

Refer to Web version on PubMed Central for supplementary material.

\section{ACKNOWLEDGMENT}

This material is based upon work supported by the NIH Postdoctoral Fellowship Program under Grant No. 1F32GM125163 (A.A.T.), Leopoldina - National Academy of Science under Grant No. LPDS2017-08 (K.S.) and the NIH (Grant No. GM122483 and R35GM128779). Any opinions, findings, conclusions, or recommendations expressed in this material are those of the authors and do not necessarily reflect the views of the NIH. We are grateful to Drs. Peter Müller and Charlene Tsay for crystallographic analysis, and we acknowledge Richard Liu and Drs. Christine Nguyen and Scott McCann for assistance in the preparation of this manuscript. Calculations were performed at the Center for Research Computing at the University of Pittsburgh and the Extreme Science and Engineering Discovery Environment (XSEDE) supported by the NSF.

\section{REFERENCES}

(1). Zhu S; Niljianskul N; Buchwald SL J. Am. Chem. Soc. 2013, 135, 15746-15749. [PubMed: 24106781]

(2). Miki Y; Hirano K; Satoh T; Miura M Angew. Chem. Int. Ed. 2013, 52, 10830-10834.

(3). (a) Pirnot MT; Wang YM; Buchwald SL Angew. Chem. Int. Ed. 2016, 55, 48-57.(b) Zhu S; Buchwald SL J. Am. Chem. Soc. 2014, 136, 15913-15916. [PubMed: 25339089]

(4). Niljianskul N; Zhu S; Buchwald SL Angew. Chem. Int. Ed. 2015, 54, 1638-1641.

(5). (a) Shi SL; Buchwald SL Nat Chem. 2015, 7, 38-44. [PubMed: 25515888] (b) Severin R; Doye S Chem. Soc. Rev. 2007, 36, 1407-1420. [PubMed: 17660874]

(6). (a) Friis SD; Pirnot MT; Dupuis LN; Buchwald SL Angew. Chem. Int. 2017, 56, 7242-7246.(b) Yang Y; Shi SL; Niu D; Liu P; Buchwald SL Science. 2015, 349, 62-66. [PubMed: 26138973]

(7). For representative examples of other methods of hydroamination, see:(a) Musacchio AJ; Lainhart BC; Zhang X; Naguib SG; Sherwood TC; Knowles RR Science. 2017, 355, 727-750. [PubMed: 28209894] (b) Ensign SC; Vanable EP; Kortman GD; Weir LJ; Hull KL J. Am. Chem. Soc. 2015, 137, 13748-13751. [PubMed: 26456593] (c) Nguyen TM; Manohar N; Nicewicz DA; Angew. Chem. Int. 2014, 53, 6198-6201.(d) Banerjee D; Junge K; Beller M Org. Chem. Front. 2014, 1, 368-372.(e) Rucker RP; Whittaker AM; Dang H; Lalic GJ Am. Chem. Soc. 2012, 134, 65716574.(f) Shapiro ND; Rauniyar V; Hamilton GL; Wu J; Toste D Nature, 2011, 470, 245-249. [PubMed: 21307938] (g) Seayad J; Tillack A; HArtung CG; Beller M Adv. Synth. Catal. 2002, 344, 795-813.(h) Schlummer B; Hartwig JF Org. Lett. 2002, 1471-1474. [PubMed: 11975606]

(8). (a) Bernoud E;Lepori C; Mellah M; Schulz E; Hannedouche J Catai. Sci. Technol. 2015, 5, $2017-$ 2037.(b) Hultzsch KC Org. Biomol. Chem. 2005, 3, 1819-1824. [PubMed: 15889160]

(9). Dewick PM Medicinal natural products: a biosynthetic approach, 3rd edition ed., Wiley, Chichester, West Sussex, England; New York, NY, USA, 2009.

(10). For reviews of methods for the synthesis of amines, see:(a) Baxter EW; Reitz AB Organic Reactions 2002, 59, 1-741.(b) Chiral Amine Synthesis; Nugent TC, Ed.; Wiley-VCH: Weinheim, 2010. 
(11). Liu RY; Buchwald SL Org. Synth. 2018, 95, 80-96. [PubMed: 30287975]

(12). Bandar JS; Pirnot MT; Buchwald SL J. Am. Chem. Soc. 2015, 137, 14812-14818. [PubMed: 26522837]

(13). For representative examples of aminoboration, see:(a) Xi Y; Hartwig JF J. Am. Chem. Soc. 2017, 139, 12758-12772. [PubMed: 28787137] (b) Lee J; Radomkit S; Torker S; Pozo JD; Hoveyda AH Nat. Chem. 2017, 10, 99-108. [PubMed: 29256506]

(14). (a) Lu G; Liu RY; Yang Y; Fang C; Lambrecht DS; Buchwald SL; Liu PJ Am. Chem. Soc. 2017, 139, 16548-16555.(b) Tobisch S Chem. Sci. 2017, 8, 4410-4423. [PubMed: 28660063]

(15). We propose a mechanism that is consistent with all of the current data but we cannot exclude the possibility that the $\mathrm{C}-\mathrm{N}$ bond forming step occurs through an outersphere process.

(16). Echeverria J; Aullon G; Danovich D,Shaik S; Alvarez S Nature Chem, 2011, 3, 323-330. [PubMed: 21430693]

(17). (a) Neel AJ; Hilton MJ; Sigman MS; Toste FD Nature 2017, 543, 637-646. [PubMed: 28358089] (b) Wagner JP; Schreiner PR Angew. Chem., Int. Ed. 2015, 54, 12274-12296.

(18). (a) Xu X; Liu P; Lesser A; Sirois LE; Wender PA; Houk KN J. Am. Chem. Soc. 2012, 134, 11012-11025. [PubMed: 22668243] (b) Wolters LP; Koekkoek R; Bickelhaupt FM ACS Catal. 2015, 5, 5766-5775.(c) Lyngvi E; Sanhueza IA; Schoenebeck F Organometallics 2015, 34, 805812.(d) Meyer TH; Liu W; Feldt M; Wuttke A; Mata RA; Ackermann L Chem. - Eur. J. 2017, 23, 5443-5447. [PubMed: 28317205] (e) Cundari TR; Jacobs BP; MacMillanb SN; Wolczanski PT Dalton Trans, 2018, 47, 6025-6030. [PubMed: 29687794]

(19). (a) Hale LVA; Szymczak NK ACS Catal. 2018, 8, 6446-6461.(b) Chattopadhyay B; Dannatt JE; Sanctis ILAD; Gore KA; Maleczka RE; Singleton DA; Smith MR J. Am. Chem. Soc. 2017, 139, 7864-7871. [PubMed: 28453268] (c) Davis HJ; Mihai MT; Phipps RJ J. Am. Chem. Soc. 2016, 138, 12759-12762 [PubMed: 27626468] (d) Kuninobu Y; Ida H; Nishi M; Kanai M Nat. Chem. 2015, 7, 712-717. [PubMed: 26291942]

(20). (a) Kui SCF; Zhu N; Chan MCW Angew. Chem. Int. Ed. 2003, 42, 1628-1632.(b) Mitani M; Mohri J; Yoshida Y; Saito J ; Ishii S; Tsuru K; Matsui S; Furuyama R; Nakano T; Tanaka H; Kojoh S; Matsugi T; Kashiwa N; Fujia TJ Am. Chem. Soc, 2002, 124, 13, 3327-3336.

(21). (a) Luo SX; Engle KM; Dong X; Heji A; Takase MK; Henling LM; Liu P; Houk KN; Grubbs RH ACS Catal. 2018, 8, 4600-4611.(b) Burrows LC; Jesikiewicz LT; Lu G; Geib SJ; Liu P; Brummond KM J. Am. Chem. Soc. 2017, 139, 15022-15032. [PubMed: 29022341]

(22). (a) Straker RN; Mekareeya A; Paton RS; Anderson EA Nat. Commun. 2016, 7, 10109-10118. [PubMed: 26728968] (b) Kwon D; Fuller JT; Kilgore UJ; Sydora OL; Bischof SM; Ess DH ACS Catal, 2018, 8, 1138-1142.(c) Nielsen MC; Bonney KJ; Schoenebeck F Angew. Chem. Int. Ed. 2014, 53, 5903-5906.(d) Bernales V; League AB; Li Z; Schweitzer NM; Peters AW; Carlson RK; Hupp JT; Cramer CJ; Farha OK; Gagliardi LJ Phys. Chem. C 2016, 120, 23576-23583.(e) Sinha I; Lee Y; Bae C; Tussupbayev S; Lee Y; Seo M; Kim J; Baik M; Lee Y; Kim H Catal. Sci. Technol, 2017, 7, 4375-4387.(f) Wang Y; Wang J; Su J; Huang F; Jiao L; Liang Y; Yang D; Zhang S; Wender PA; Yu Z-XJ Am. Chem. Soc. 2007, 129, 10060-10061.(g) Occhipinti G; Koudriavtsev V; Törnroos KW; Jensen VR Dalton Trans. 2014, 43, 11106-11117. [PubMed: 24788021]

(23). Ligands L2 and L3 were prepared according to: Sevov CS; Hartwig JF J. Am. Chem. Soc, 2014, 136, 10625-10631. [PubMed: 25032781]

(24). The hydrocupration event has been shown previously to be the rate determining step for terminal olefins with DTBM-SEGPHOS, see ref 13. Additionally, ligand L6 exhibited clean first order profiles along with a first order dependence on the olefin substrate, see supplementary material.

(25). Macphee JA; Panaye A; Dubois JE Tetrahedron, 1978, 34, 2253-3562.

(26). O’Hagan D Chem. Soc. Rev.2008, 37, 308-319. [PubMed: 18197347]

(27). Iwamoto H; Imamoto T; Ito H Nat. Commun. 2018, 9, 2290. [PubMed: 29895938]

(28). (a) Guan Y; Wheeler SE Angew. Chem. Int. Ed. 2017, 56, 9101 -9105.(b) Poree C; Schoenebeck F Acc. Chem. Res, 2017, 50, 605-608. [PubMed: 28945392]

(29). Sperger T; Sanhueza IA; Schoenebeck F Acc. Chem. Res, 2016, 49, 1311-1319. [PubMed: 27171796] 
(30). Frisch MJ; Trucks GW; Schlegel HB; Scuseria GE; Robb MA; Cheeseman JR; Scalmani G; Barone V; Mennucci B; Petersson GA; Nakatsuji H; Caricato M; Li X; Hratchian HP; Izmaylov AF; Bloino J; Zheng G; Sonnenberg JL; Hada M; Ehara M; Toyota K; Fukuda R; Hasegawa J; Ishida M; Nakajima T; Honda Y; Kitao O; Nakai H; Vreven T; Montgomery JA Jr.; Peralta JE; Ogliaro F; Bearpark M; Heyd JJ; Brothers E; Kudin KN; Staroverov VN; Kobayashi R; Normand J; Raghavachari K; Rendell A; Burant JC; Iyengar SS; Tomasi J; Cossi M; Rega N; Millam NJ; Klene M; Knox JE; Cross JB; Bakken V; Adamo C; Jaramillo J; Gomperts R; Stratmann RE; Yazyev O; Austin AJ; Cammi R; Pomelli C; Ochterski JW; Martin RL; Morokuma K; Zakrzewski VG; Voth GA; Salvador P; Dannenberg JJ; Dapprich S; Daniels AD; Farkas Ö; Foresman JB; Ortiz JV; Cioslowski J; Fox DJ Gaussian 09, Revision D.01; Gaussian, Inc: Wallingford, CT, 2009.

(31). (a) Lee C; Yang W; Parr RG Phys. Rev. B 1988, 37, 785;(b) Becke AD J. Chem. Phys. 1993, 98, 5648-5652.

(32). Ribeiro RF; Marenich AV; Cramer CJ; Truhlar DG J. Phys. Chem. B 2011, 115, 14556-14562. [PubMed: 21875126]

(33). (a) Cossi M; Rega N; Scalmani G; Barone VJ Comp. Chem, 2003, 24, 669-681.(b) Barone V; Cossi MJ Phys. Chem. A, 1998, 102, 1995-2001.

(34). Chai JD; Head-Gordon M Phys. Chem. Chem. Phys, 2008, 10, 6615-6620. [PubMed: 18989472]

(35). Bickelhaupt FM; Houk KN Angew. Chem., Int. Ed. 2017, 56, 10070-10086.

(36). (a) Peverati R; Truhlar DG J. Phys. Chem. Lett, 2011, 21, 2810-2817.b) Burns LA; VázquezMayagoitia A; Sumpter BG; Sherrill CD J. Chem. Phys. 2011, 134, 084107. [PubMed: 21361527]

(37). (a) Distasio RA Jr., ; Head-Gordon M Mol. Phys. 2007, 105, 1073-1083.(b) Steele RP; DiStasio RA; Shao Y; Kong J; Head-Gordon MJ Chem. Phys. 2006, 125, 074108.

(38). (a) Horn PR; Head-Gordon MJ Chem. Phys. 2016, 144, 084118.(b) Horn PR; Mao Y; HeadGordon MJ Chem. Phys.2016, 144, 114107.(c) Horn PR; Mao Y; Head-Gordon M Phys. Chem. Chem. Phys, 2016, 18, 23067-23079. [PubMed: 27492057]

(39). Shao Y; Gan Z; Epifanovsky E; Gilbert ATB; Wormit M; Kussmann J; Lange AW; Behn A; Deng J; Feng X; Ghosh D; Goldey M; Horn PR; Jacobson LD; Kaliman I; Khaliullin RZ; Kus T; Landau A; Liu J; Proynov EI; Rhee YM; Richard RM; Rohrdanz MA; Steele RP; Sundstrom EJ; Woodcock HL; Zimmerman PM; Zuev D; Albrecht B; Alguire E; Austin B; Beran GJO; Bernard YA; Berquist E; Brandhorst K; Bravaya KB; Brown ST; Casanova D; Chang C-M; Chen Y; Chien SH; Closser KD; Crittenden DL; Diedenhofen M; DiStasio RA; Do H; Dutoi AD; Edgar RG; Fatehi S; Fusti-Molnar L; Ghysels A; Golubeva-Zadorozhnaya A; Gomes J; Hanson-Heine MWD; Harbach PHP; Hauser AW; Hohenstein EG; Holden ZC; Jagau T-C; Ji H; Kaduk B; Khistyaev K; Kim J; Kim J; King RA; Klunzinger P; Kosenkov D; Kowalczyk T; Krauter CM; Lao KU; Laurent AD; Lawler KV; Levchenko SV; Lin CY; Liu F; Livshits E; Lochan RC; Luenser A; Manohar P; Manzer SF; Mao S-P; Mardirossian N; Marenich AV; Maurer SA; Mayhall NJ; Neuscamman E; Oana CM; Olivares-Amaya R; O’Neill DP; Parkhill JA; Perrine TM; Peverati R; Prociuk A; Rehn DR; Rosta E; Russ NJ; Sharada SM; Sharma S; Small DW; Sodt A Mol. Phys. 2015, 113, 184-215

(40). The corresponding diarylchlorophosphine resulted in no product formation; see: Liu L; Wu HC; Yu JQ; Chem. Eur. J. 2011, 17, 10828-10831. [PubMed: 21853488]

(41). Colloidal copper was observed after a few minutes along with the observation of unbound L5.

(42). The structure of L6 was additionally validated by single crystal X-ray analysis (see supplementary information for details).

(43). The reactions of substrates incorporating an imidazole unit resulted in no product formation, presumably due to the imidazole's Lewis basicity. 
a)

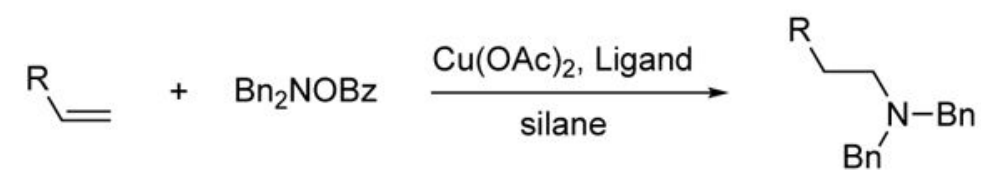

b)

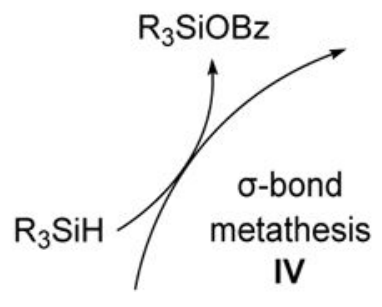

LCuH

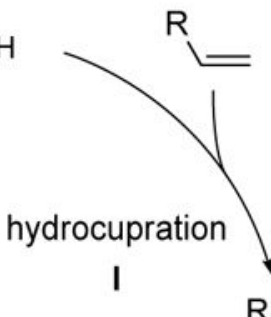

LCuOBz
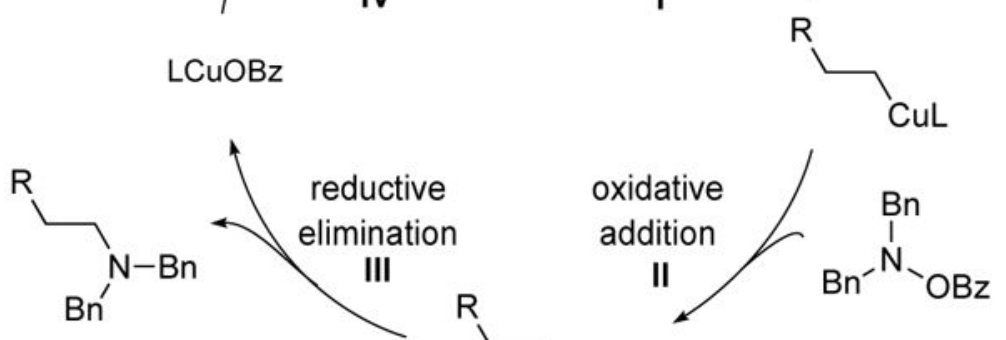<smiles>[R]CCC(I)(OC(=O)O)N(Cc1ccccc1)Cc1ccccc1</smiles>

RDS for activated substrates $=\sigma$-bond metathesis RDS for unactivated substrates = hydrocupration

C)<smiles>Cc1ccc(Pc2ccc3c(c2-c2c(Pc4ccccc4)ccc4c2OCO4)OCO3)cc1</smiles>

SEGPHOS L1<smiles>COc1c(C(C)(C)C)cc(CPc2ccc3c(c2-c2c(Pc4cc(C(C)(C)C)c(OC)c(C(C)(C)C)c4)ccc4c2OCO4)OCO3)cc1C(C)(C)C</smiles>

DTBM-SEGPHOS L2

Figure 1.

a) LCuH-catalyzed anti-Markovnikov hydroamination reaction. b) Proposed catalytic cycle for LCuH-catalyzed anti-Markovnikov hydroamination reaction. c) SEGPHOS L1 and DTBM-SEGPHOS L2 ligands. 
a) Ligand-substrate interaction model to dissect activation energies

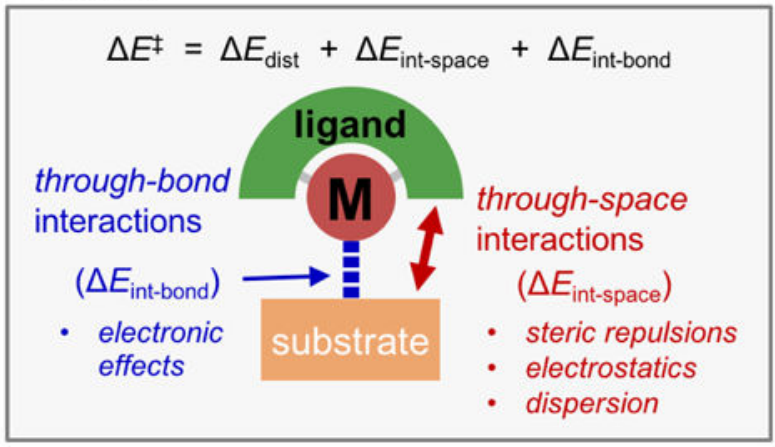

b) Ligand-substrate dispersion interactions in hydrocupration transition state

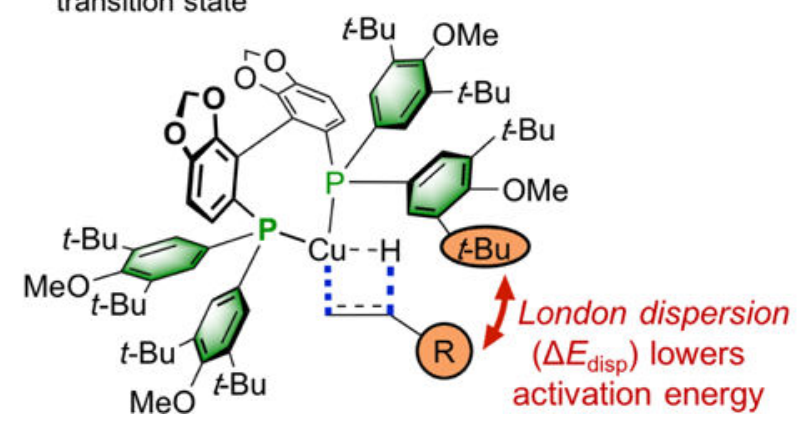

Figure 2.

a) Ligand-substrate interaction model to study the origin of reactivity in hydrocupration. b) London dispersion interactions lowering the hydrocupration barrier for $\mathbf{L} \mathbf{2} \mathbf{C u H}$. 


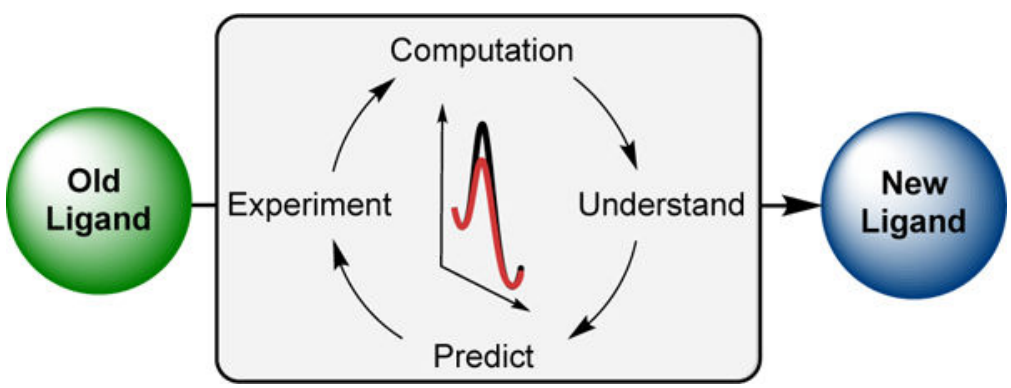

Figure 3.

Project outline. 


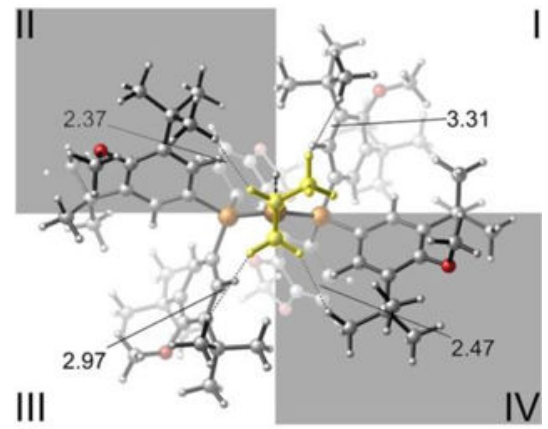

TS-2, L = DTBM-SEGPHOS (L2)

$\Delta G^{\ddagger}=20.2 \mathrm{kcal} / \mathrm{mol}$

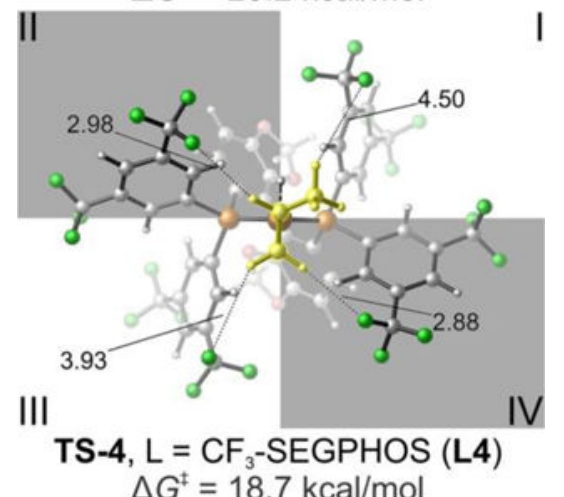

Figure 4.

Optimized geometries of hydrocupration transition states with the DTBM-SEGPHOS (TS-2) and $\mathrm{CF}_{3}$-SEGPHOS ligands (TS-4). Distances are in Ångström $[\AA]$. 


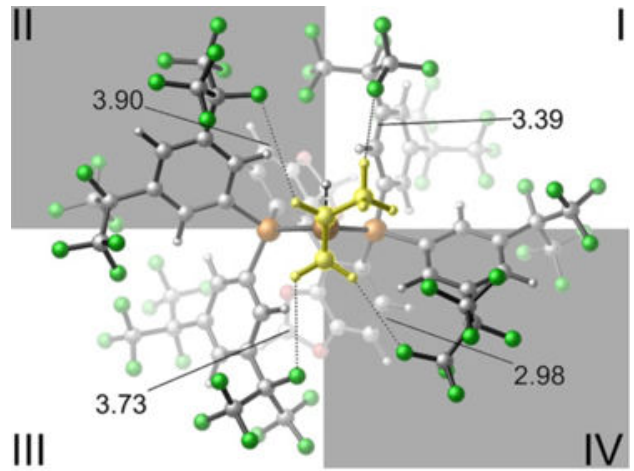

TS-5, L $=i-\mathrm{C}_{3} \mathrm{~F}_{7}-\mathrm{SEGPHOS}(\mathbf{L 5})$ $\Delta G^{\ddagger}=17.2 \mathrm{kcal} / \mathrm{mol}$

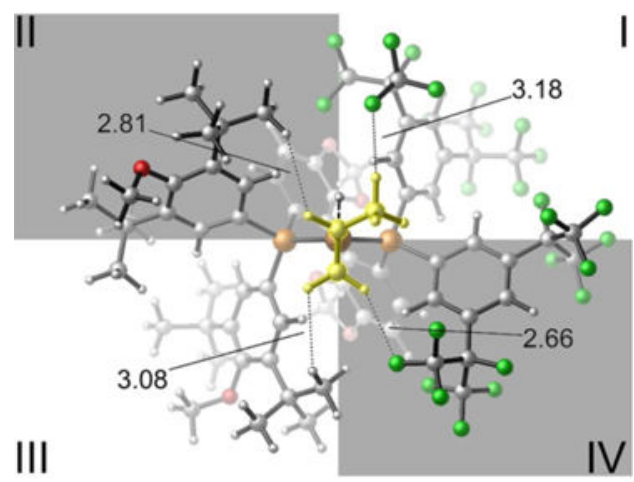

TS-6, L = DTBM- $i-\mathrm{C}_{3} \mathrm{~F}_{7}-\mathrm{SEGPHOS}(\mathrm{L6})$ $\Delta G^{\ddagger}=17.0 \mathrm{kcal} / \mathrm{mol}$

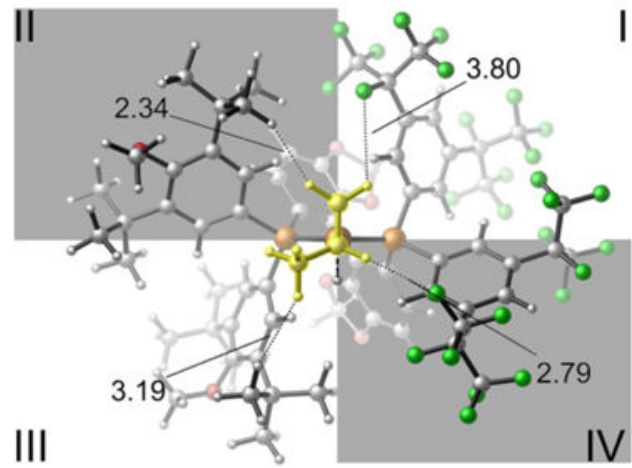

TS-6a, L = DTBM-i- $\mathrm{C}_{3} \mathrm{~F}_{7}$-SEGPHOS (L6) (Less stable isomer of TS6)

$$
\Delta G^{\ddagger}=19.6 \mathrm{kcal} / \mathrm{mol}
$$

Figure 5.

Optimized geometries of hydrocupration transition states with the $i-\mathrm{C}_{3} \mathrm{~F}_{7}$-SEGPHOS (TS-5) and the hybrid DTBM- $i-\mathrm{C}_{3} \mathrm{~F}_{7}-\mathrm{SEGPHOS}$ ligand (TS-6 and TS-6a). Distances are reported in Ångström [̊̊]. 

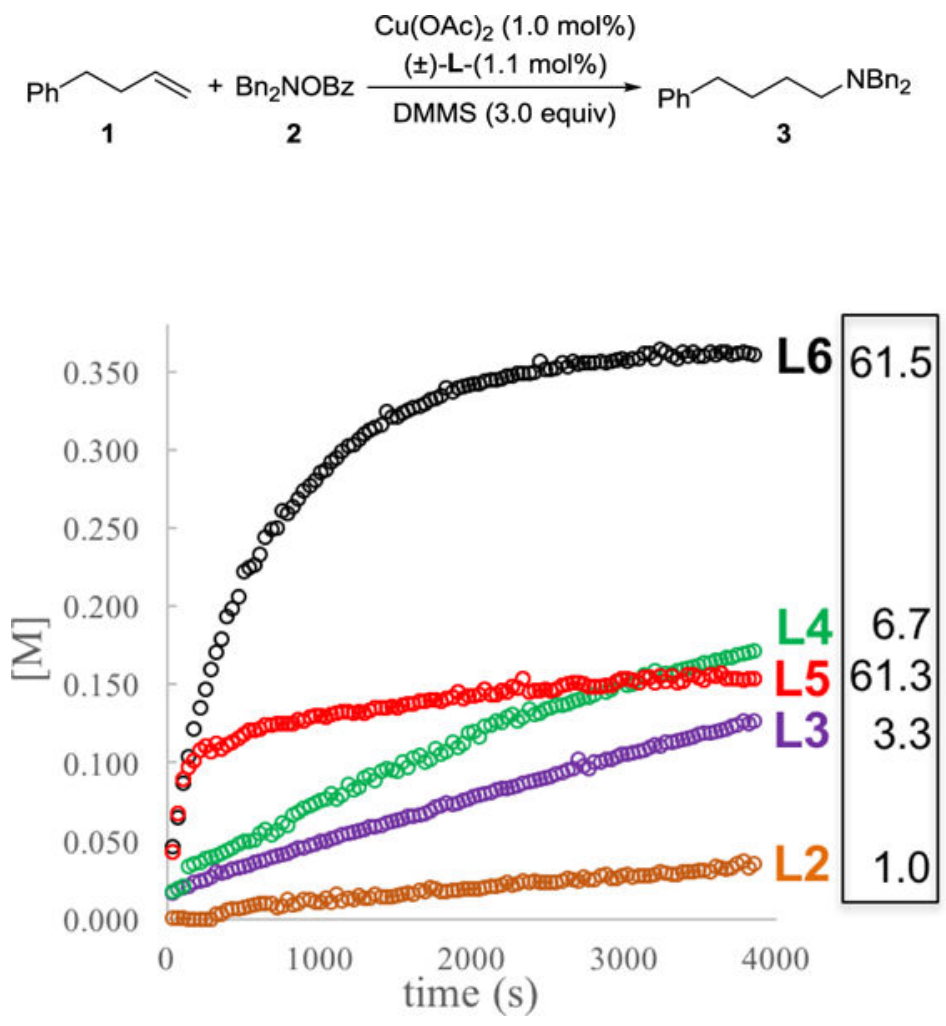

Figure 6.

Combined data for the formation of amination product $\mathbf{3}$ (see, supplementary information for details). 

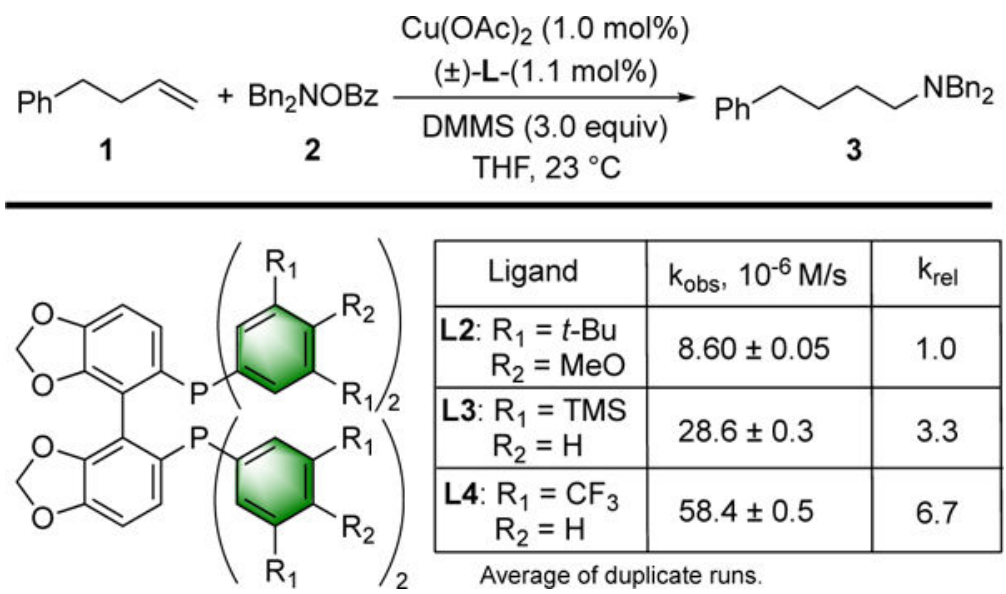

Scheme 1.

Initial kinetic analysis for symmetric ligands $\mathbf{L 2}, \mathbf{L 3}$ and $\mathbf{L 4}$. 
a)<smiles>Brc1ccc2c(c1-c1c(Br)ccc3c1OCO3)OCO2</smiles>

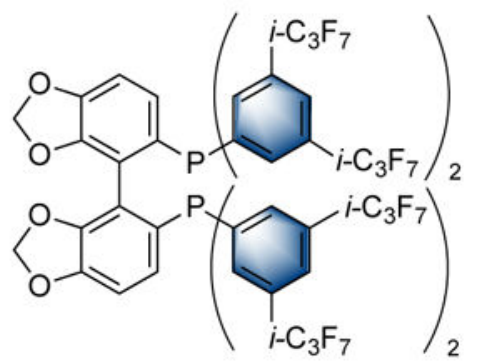

5

L5

b)

1) $n$-BuLi, $\mathrm{MgBr}_{2}, \mathrm{Ar}_{2} \mathrm{PBr} 6$

2) $\mathrm{CODPd}\left(\mathrm{CH}_{2} \mathrm{TMS}\right)_{2}$,

$5 \underset{\mathrm{Cs}_{2} \mathrm{CO}_{3}, \mathrm{Ar}_{2} \mathrm{P}(\mathrm{O}) \mathrm{H} 7}{\stackrel{\mathrm{Et}_{3} \mathrm{~N}, \mathrm{HSiCl}_{3}}{\longrightarrow}}$

( $26 \%, 3$ steps)

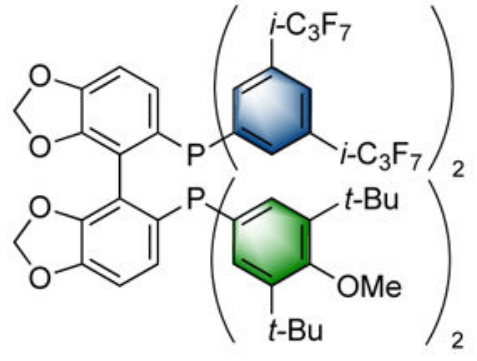

L6

Scheme 2.

Synthesis of SEGPHOS derivatives L5 and L6 (see supplementary information for details). 


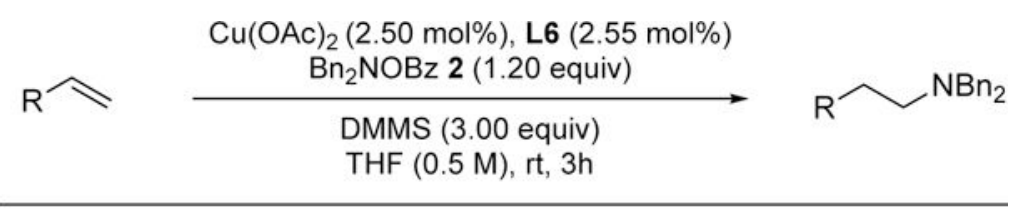<smiles>CCCCCCCCCCCCCCCCCCCC</smiles><smiles>CCCCCCCOc1ccc(C(=O)OC(C)CC)cc1</smiles>

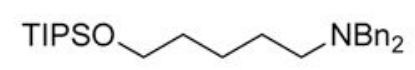

$10(94 \%)$<smiles>CC1(C)COC(CCCCC(=O)c2ccccc2)OC1</smiles>

11 (79\%)<smiles>CC(C)(C)CCCCCC(=O)N1CCN(C(=O)c2ccccc2)CC1</smiles><smiles>CCCCCNCCCCCN1CCOCC1</smiles>

12 (91\%)

13 (90\%)<smiles>CC(C)(C)CCCCCOCCc1cccs1</smiles><smiles>Cc1cn(CCCCCNCc2ccccc2)c2ccccc12</smiles>

14 (91\%)

$15(91 \%)^{a}$<smiles>CCCCCCCCCOc1nc2ccccc2s1</smiles><smiles>CCCCCCCCCCOc1ncccn1</smiles>

$16(96 \%)^{a}$<smiles>Cc1cc(OCCCCCC(C)(C)C)ccc1-c1cc(C)c2ccccc2n1</smiles>

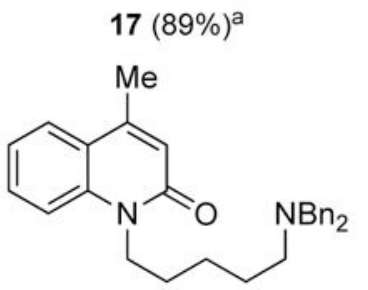

$18(89 \%)^{\mathrm{a}}$

$19(82 \%)^{a}$

Scheme 3.

Isolated yields are reported as the average of two runs. Standard reaction conditions: terminal olefin ( $0.50 \mathrm{mmol}), \mathrm{Bn}_{2} \mathrm{NOBz}(2)(0.60 \mathrm{mmol}), \mathrm{Cu}(\mathrm{OAc})_{2}(2.50 \mathrm{~mol} \%), \mathbf{L 6}(2.55$ mol\%), DMMS (1.50 mmol), THF (1.0 mL), $23{ }^{\circ} \mathrm{C}, 3 \mathrm{~h} .{ }^{a} 40{ }^{\circ} \mathrm{C} .{ }^{b}$ DTBM-SEGPHOS was used in place of $\mathbf{L 6}$ and NMR yields are provided. 
Table 1.

Activation free energies of the hydrocupration transition states and energy components derived from the ligand-substrate interaction model. ${ }^{a}$

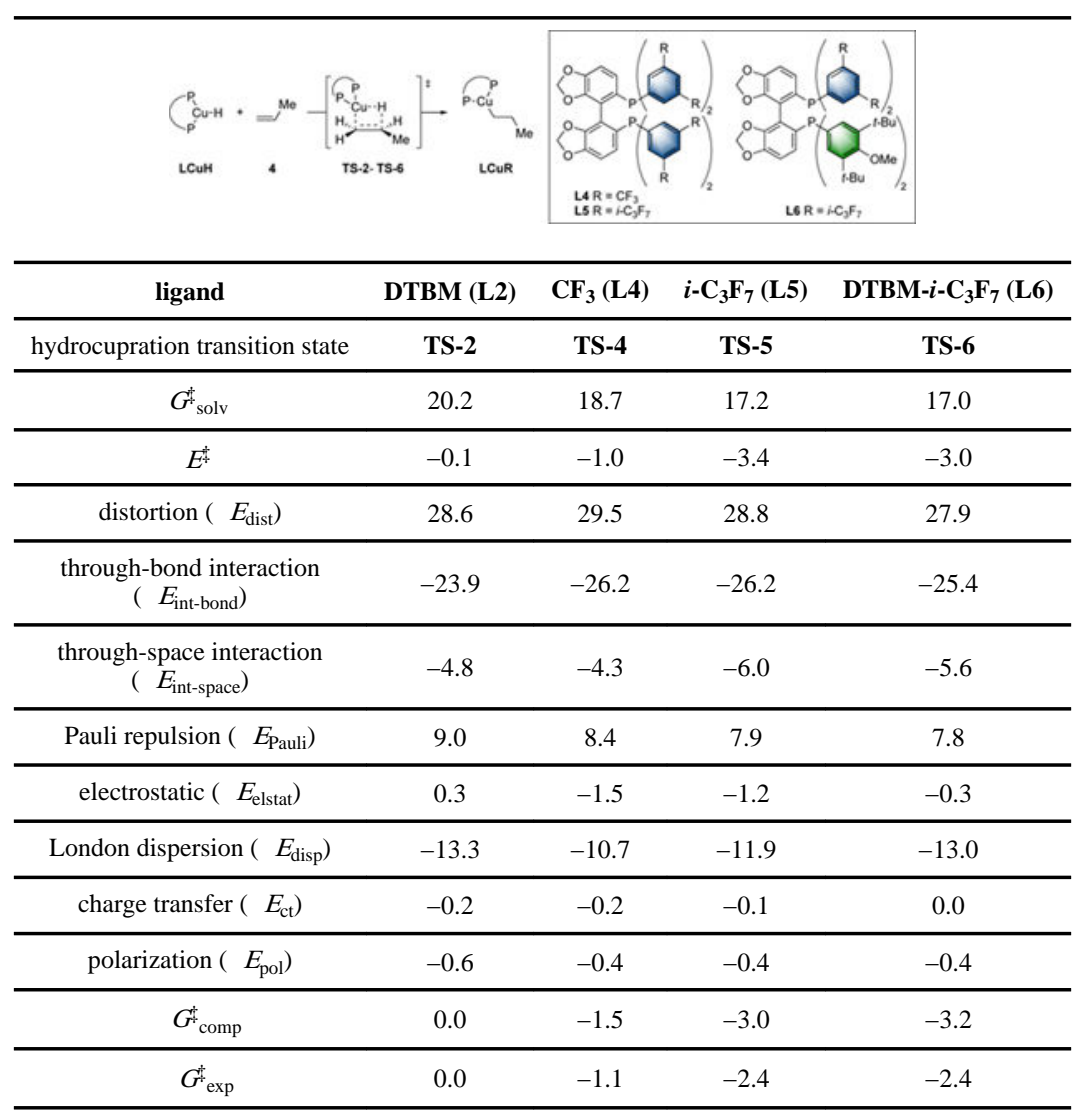

${ }^{a}$ All energies are reported in kcal/mol. The activation energies $\left(\Delta G^{\ddagger}\right.$ solv and $\left.\Delta E^{\ddagger}\right)$ are with respect to the separated CuH catalyst and propene (4). $\Delta \Delta G^{\ddagger}$ comp values were calculated by subtracting $\Delta G^{\ddagger}$ solv-L2 from $\Delta G^{\ddagger}$ solv-LX. $\Delta \Delta G^{\dagger}$ exp were derived from the experimental relative rate constants $\left(k_{\text {rel }}\right)$. 